\title{
ZIRCONIUM OXIDE STABILIZED BY SCANDIUM (III) AND CERIUM (IV) COMPLEX OXIDES AS THE BASIS FOR PREPARATION OF THICK FILMS AND MULTILAYER STRUCTURES FOR LOW TEMPERATURE $\left(600^{\circ} \mathrm{C}\right)$ FUEL CELL
}

\author{
Oleksandr D. Vasylyeva, Yehor M. Brodnikovskyi ${ }^{\mathrm{a}}$, \\ Oleg I. V'yunov $^{\mathrm{b}}$, Leonid L. Kovalenko ${ }^{\mathrm{b}}$, Oleg Z. Yanchevskii ${ }^{\mathrm{b}}$, Anatolii G. Belous ${ }^{\mathrm{b}}$. \\ ${ }^{a}$ Laboratory for SOFC, Institute for Problems of Materials Science, Ukrainian NAS, \\ Krzhyzhanovskyi Str. 3, Kiev 03142, Ukraine \\ ${ }^{b}$ Department of Solid State Chemistry, V.I. Vernadskii Institute of General \& Inorganic Chemistry, \\ Ukrainian NAS, Palladina ave. 32/34, Kiev 03680, Ukraine \\ e-mail:vyunov@ionc.kiev.ua
}

Keywords: stabilized zirconium dioxide, deposition, tape casting, thick-film multilayer system.

Weakly agglomerated zirconium dioxide nanopowders stabilized by complex oxides of scandium (III) and cerium (IV) were synthesized by precipitation from aqueous solutions. Using weakly agglomerated nanopowders, thick films were prepared by tape casting on $a-\mathrm{Al}_{2} \mathrm{O}_{3}$ substrates. These thick films have high oxygen conductivity; and their electron conductivity is lower than oxygen conductivity by 4 orders of magnitude. A multilayer system consisting of films of polycrystalline porous anode and solid electrolyte was prepared. The diffusion of cations in the anode boundary layer and change in the chemical composition of the electrolyte film are not observed at optimum synthesis conditions.

\section{Introduction}

Solid oxide fuel cell (SOFC) generates electric current due to chemical reaction at electrodes followed by $\mathrm{O}^{2-}$ ion transfer from the porous cathode through dense solid electrolyte to the porous anode. Cubic zirconium dioxide $\left(\mathrm{c}-\mathrm{ZrO}_{2}\right)$ stabilized by oxides of rare-earth elements in a wide temperature range is used as the solid electrolyte and the basis for deposition of anode [1-3]. Today the development of SOFC systems operating at low temperature $\left(600-700{ }^{\circ} \mathrm{C}\right)$ is of particular interest. Reducing the thickness of solid electrolyte below $5 \mu \mathrm{m}$ and using SOFC of film construction reduces ohmic losses and significantly increases the power density of solid oxide fuel cells. Increasing the oxygen conductivity of solid electrolyte based on stabilized $\mathrm{ZrO}_{2}$ would reduce the operating temperature of the SOFC [4,5]. The most accessible and cheap method of preparation of thick films and multilayer systems based on them for mass production is 
tape casting. Zirconium dioxide stabilized by complex oxides of scandium (III) and cerium (IV) is highly-conductive by oxygen and is promising as solid electrolyte [6-8]. Therefore, the present work is aimed at finding the optimal conditions of deposition (tape casting) of zirconium oxide thick films stabilized by complex oxides of scandium (III) and cerium (IV) and preparation of multilayer solid oxide fuel cells based on them.

\section{Experimental part}

Weakly agglomerated nanopowders were precipitated from a solution in two stages in order to avoid agglomeration of the precipitates and to get crisp and soft powders. Aqueous solutions of analytically pure $\mathrm{ZrOCl}_{2}, \mathrm{Sc}\left(\mathrm{NO}_{3}\right)_{3}$, $\mathrm{Ce}\left(\mathrm{NO}_{3}\right)_{3}$ and chemically pure $\mathrm{NH}_{4} \mathrm{OH}$ were used as initial reagents. In the first stage, zirconium hydroxide was precipitated at $\mathrm{pH}=4$ 4.5. In the second stage, scandium and cerium hydroxides were precipitated at higher $\mathrm{pH}$ (8.59.0). Precipitates were washed on a filter with distilled water to completely remove $\mathrm{Cl}^{-}, \mathrm{NO}^{3-}$, $\mathrm{NH}^{4+}$ ions and dried at $100-110{ }^{\circ} \mathrm{C}$. Then they were heat treated at $600{ }^{\circ} \mathrm{C}$ for 2 hours.

Thick films based on weakly agglomerated nanopowders $\mathrm{ZrO}_{2}-\mathrm{Sc}_{2} \mathrm{O}_{3}-\mathrm{CeO}_{2}$ were deposited on $a-\mathrm{Al}_{2} \mathrm{O}_{3}$ (polycor) substrates using Film Applicator and Drying Time Recorder Coatmaster 510 (Erichsen, Germany). After drying in air, the films were heat treated at different temperatures and heating/cooling rates.
Samples were examined by X-ray diffraction (XRD) using a DRON-3M diffractometer (CuKa-radiation, Ni-filter) [9]. Particle size was studied using TEM JEM-1230 (Jeol). The investigation of microstructure of films, and quantitative microanalysis of elements were carried out with a scanning electron microscope Jeol JSM 6510 equipped with energy-dispersive X-ray (EDX) spectrometer JED-2201 (Japan). Data for impedance analysis in the range from 1 $\mathrm{Hz}$ to $32 \mathrm{MHz}$ were collected using an impedance analyzer 1260A Impedance / GainPhase Analyzer (Solartron Analytical). Planar platinum electrodes were deposited on thick films by DC magnetron sputtering.

\section{Results and discussion}

Sequential deposition at optimum $\mathrm{pH}$ leads to the formation of weakly agglomerated nanopowders $\mathrm{ZrO}_{2}-\mathrm{Sc}_{2} \mathrm{O}_{3}-\mathrm{CeO}_{2}$, which are easily washed $\left(K_{\text {filtr }}=(0.8-1.5) \times 10^{-5} \mathrm{~cm} / \mathrm{sec}\right)$ in contrast to precipitates of the same composition, but prepared by co-deposition $\left(\mathrm{K}_{\mathrm{filtr}}=(2-5) \times 10^{-7} \mathrm{~cm} / \mathrm{sec}\right)$. XRD shows that nanopowders are amorphous after heat treatment at temperature below $450{ }^{\circ} \mathrm{C}$, and they have cubic crystal symmetry above $450{ }^{\circ} \mathrm{C}$. After heat treatment at $600{ }^{\circ} \mathrm{C}$, the particle size was $40-150 \mathrm{~nm}$, which is optimal size for the preparation of thick films based on them.

Figure 1 shows XRD patterns of thick film $\mathrm{ZrO}_{2}-\mathrm{Sc}_{2} \mathrm{O}_{3}-\mathrm{CeO}_{2}$ sintered at $1400{ }^{\circ} \mathrm{C}$ for $2 \mathrm{~h}$. XRD shows that thick film is a single phase. 


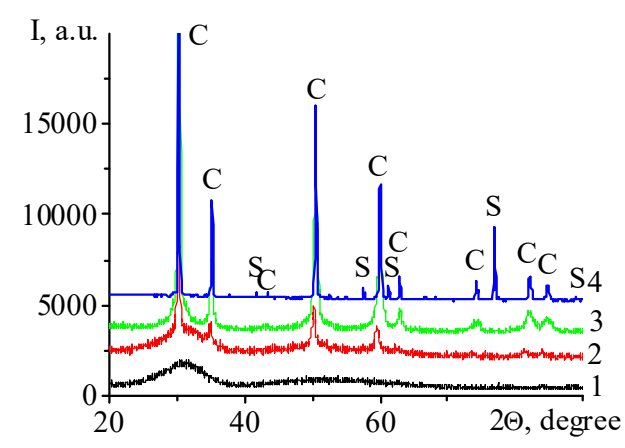

Figure 1. XRD patterns of nanopowders $\mathrm{ZrO}_{2}-\mathrm{Sc}_{2} \mathrm{O}_{3}$ $\mathrm{CeO}_{2}$ after heat treatment at $400(1), 450(2)$, and $600{ }^{\circ} \mathrm{C}$ (3); and thick film based on them after heat treatment $1400{ }^{\circ} \mathrm{C}(4)$. $\mathrm{C}$ and $\mathrm{S}$ denotes the reflections from cubic $\mathrm{ZrO}_{2}$ (PDF 49-1642) and $\mathrm{Al}_{2} \mathrm{O}_{3}$ substrate (PDF 46-1212).

From room temperature to $500{ }^{\circ} \mathrm{C}$ films were heated with maximum rate (thermal shock) to evaporate the organic components, and above $500{ }^{\circ} \mathrm{C}$ the rate was $60{ }^{\circ} \mathrm{C} / \mathrm{min}$.

Figure 2 shows the cross-section and the surface of thick film $\mathrm{ZrO}_{2}-\mathrm{Sc}_{2} \mathrm{O}_{3}-\mathrm{CeO}_{2}$. SEM shows that thick films are uniform dense layers over the entire $a-\mathrm{Al}_{2} \mathrm{O}_{3}$ substrate with a thickness of 15-20 microns. The grain size of the films is $0.5-1.5 \mu \mathrm{m}$. Grains of thick films $\mathrm{ZrO}_{2}-\mathrm{Sc}_{2} \mathrm{O}_{3}-\mathrm{CeO}_{2}$ after heat treatment at 1400 ${ }^{\circ} \mathrm{C}$ only begin to burn together (see Fig. 2). This is due to the fact that at this temperature liquid phase is not formed, and the structure is compacted slowly. EDX spectra of thick films $\mathrm{ZrO}_{2}-\mathrm{Sc}_{2} \mathrm{O}_{3}-\mathrm{CeO}_{2}$ showed no deviation from the stoichiometric composition.

Figure 3 shows complex impedance curves in Nyquist coordinates of thick films $\mathrm{ZrO}_{2}-$ $\mathrm{Sc}_{2} \mathrm{O}_{3}-\mathrm{CeO}_{2}$ at temperatures of $300-700{ }^{\circ} \mathrm{C}$. Plots consist of one semicircle in highfrequency range. A straight line at low frequencies, which is characteristic of blocking electrodes, is not observed for platinum electrodes. The conductivity of thick films increases with increasing temperature.
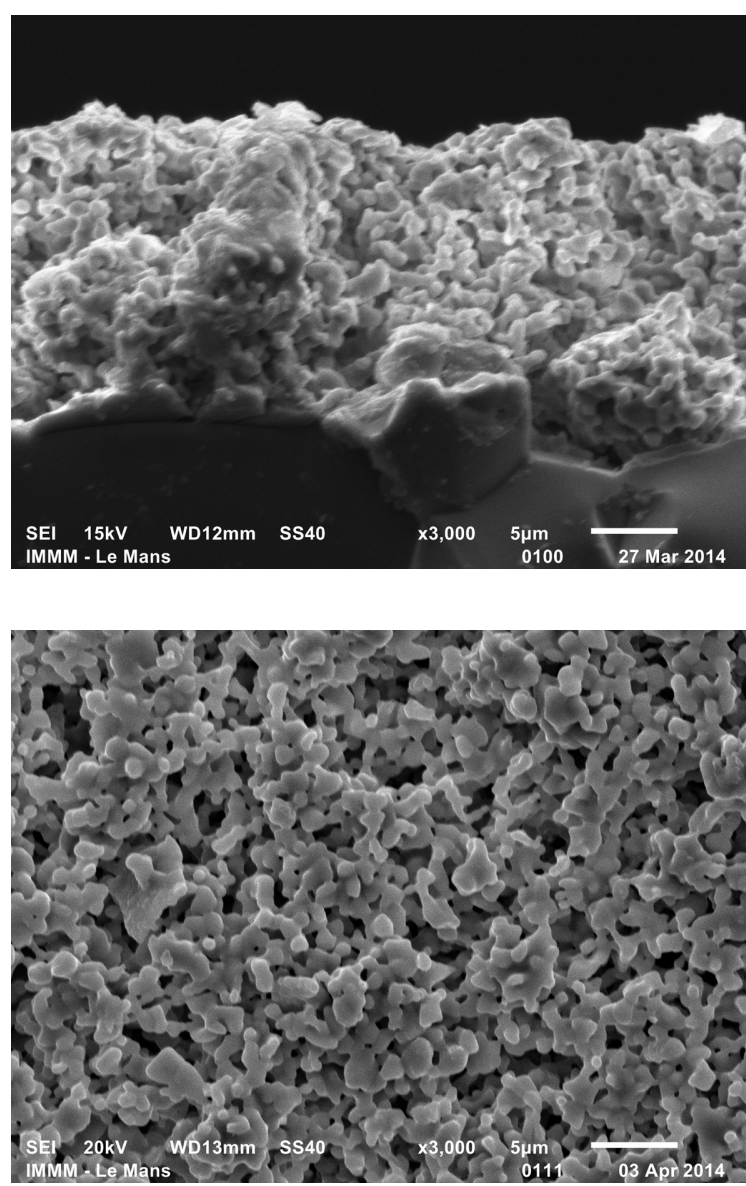

Figure 2. Microstructure of the cross-section and surface of thick film $\mathrm{ZrO}_{2}-\mathrm{Sc}_{2} \mathrm{O}_{3}-\mathrm{CeO}_{2}$. $\mathrm{T}_{\text {sint }}=1400{ }^{\circ} \mathrm{C}$.

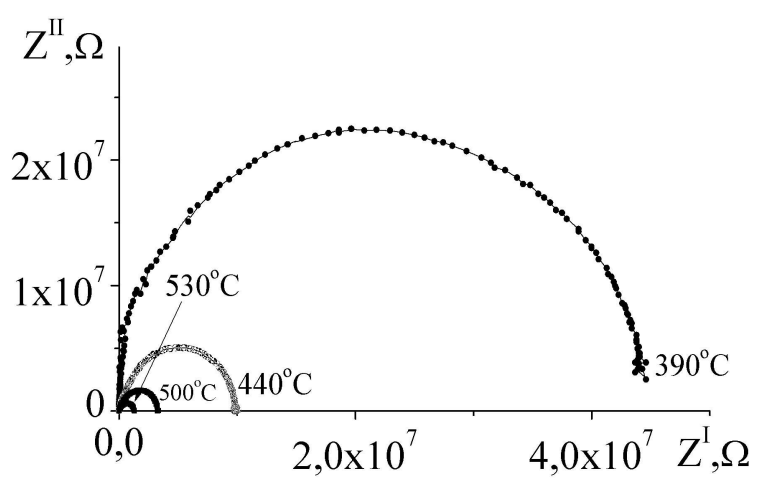

Figure 3. Complex impedance curves in Nyquist coordinates for thick films $\mathrm{ZrO}_{2}-\mathrm{Sc}_{2} \mathrm{O}_{3}-\mathrm{CeO}_{2}$ at different temperatures. 
Using complex impedance data, the temperature dependence of conductivity of thick films $\mathrm{ZrO}_{2}-\mathrm{Sc}_{2} \mathrm{O}_{3}-\mathrm{CeO}_{2}$ was determined (Figure 4), and the activation energy was calculated $\left(E_{a}=1.17 \mathrm{eV}\right)$. The conductivity of thick film $\mathrm{ZrO}_{2}-\mathrm{Sc}_{2} \mathrm{O}_{3}-\mathrm{CeO}_{2}$ is $4 \cdot 10^{-4} \mathrm{~S} / \mathrm{cm}$ at $600{ }^{\circ} \mathrm{C}$ and $2.4 \cdot 10^{-3} \mathrm{~S} / \mathrm{cm}$ at $700{ }^{\circ} \mathrm{C}$. The electron conductivity of sample is lower than oxygen conductivity by 4 orders of magnitude.

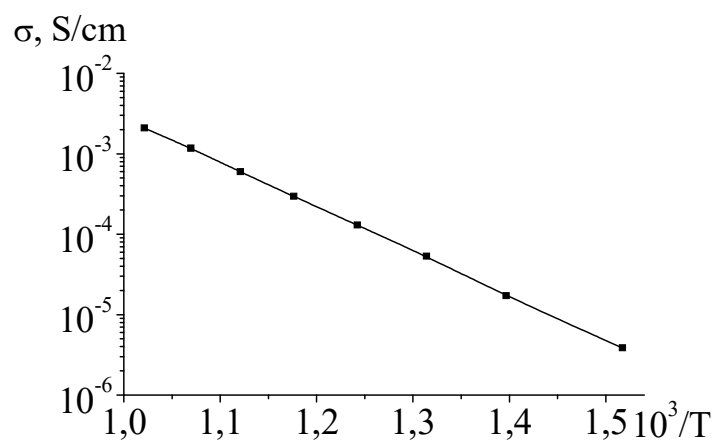

Figure 4. Temperature dependence of conductivity of thick films $\mathrm{ZrO}_{2}-\mathrm{Sc}_{2} \mathrm{O}_{3}-\mathrm{CeO}_{2}$.

Multilayer systems consisting of films of polycrystalline porous anode $\mathrm{ZrO}_{2}-\mathrm{Y}_{2} \mathrm{O}_{3}-\mathrm{NiO}$ and solid electrolyte $\mathrm{ZrO}_{2}-\mathrm{Sc}_{2} \mathrm{O}_{3}-\mathrm{CeO}_{2}$ were prepared by tape casting. Deposited slurry contained organic components (acetylacetone, isopropanol, polymethylmethacrylate, dibutyl phthalate, dibutyl phosphate, hallotannin, polyethylene glycol) and inorganic components (weakly agglomerated nanopowders $\mathrm{ZrO}_{2-}$ $\mathrm{Y}_{2} \mathrm{O}_{3}-\mathrm{NiO}$ for anode and $\mathrm{ZrO}_{2}-\mathrm{Sc}_{2} \mathrm{O}_{3}-\mathrm{CeO}_{2}$ for electrolyte). To prepare vacuum-tight films in the multilayer system, lamination was used.

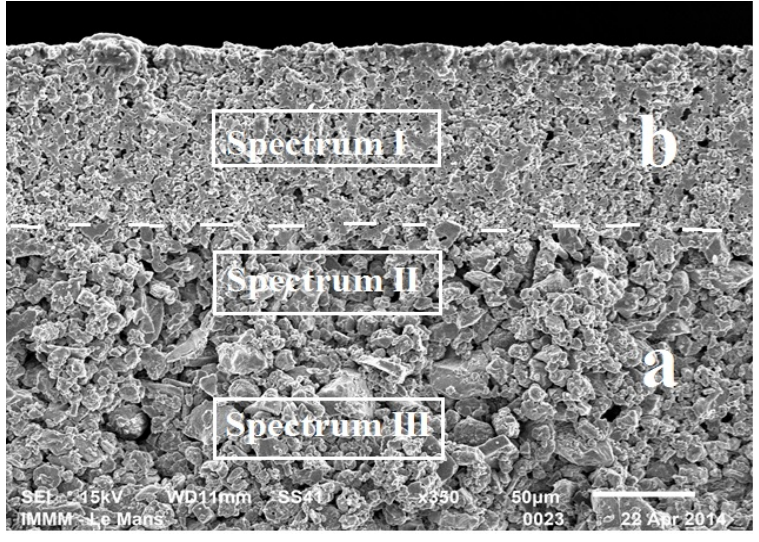

Figure 5. Microstructure of cleavage of a multilayer system including anode (a) and electrolyte (b). The areas where EDX analysis was performed are marked.

Figure 5 shows that the average thickness of the electrolyte film is about $100 \mu \mathrm{m}$. EDX analysis of multilayer electrolyte/anode system shows (Table 1) that at $1200{ }^{\circ} \mathrm{C}$ there is no significant diffusion of ions from polycrystalline anode to thick-film electrolyte and back and no change in the chemical composition of electrolyte.

Table 1. Results of EDX analysis of a multilayer anode/electrolyte system

\begin{tabular}{|c|c|c|c|c|c|}
\hline \multicolumn{2}{|c|}{ Spectrum I } & \multicolumn{2}{c|}{ Spectrum II } & \multicolumn{2}{c|}{ Spectrum III } \\
\hline Element & at. \% & Element & at. \% & Element & at. \% \\
\hline $\mathrm{O}$ & $66.3(7)$ & $\mathrm{O}$ & $51.6(5)$ & $\mathrm{O}$ & $46.8(5)$ \\
\hline $\mathrm{Sc}$ & $4.4(4)$ & $\mathrm{Ni}$ & $28.1(3)$ & $\mathrm{Ni}$ & $33.0(3)$ \\
\hline $\mathrm{Zr}$ & $27.2(4)$ & $\mathrm{Y}$ & $3.1(3)$ & $\mathrm{Y}$ & $3.5(4)$ \\
\hline $\mathrm{Ce}$ & $2.1(3)$ & $\mathrm{Zr}$ & $17.2(3)$ & $\mathrm{Zr}$ & $16.7(3)$ \\
\hline Total & 100.0 & Total & 100.0 & Total & 100.0 \\
\hline
\end{tabular}




\section{Conclusions}

Weakly agglomerated zirconium dioxide nanopowders stabilized by complex oxides of scandium (III) and cerium (IV) were synthesized by precipitation from aqueous solutions. It was established that sequentialdeposition at optimum $\mathrm{pH}$ leads to the formation of weakly agglomerated nanopowders $\mathrm{ZrO}_{2}-\mathrm{Sc}_{2} \mathrm{O}_{3}-\mathrm{CeO}_{2}$, which are easily washed $\left(\mathrm{K}_{\text {filtr }}=(0.8-1.5) \times 10^{-5} \mathrm{~cm} / \mathrm{sec}\right)$ in contrast to precipitates of the same composition, but prepared by co-deposition $\left(\mathrm{K}_{\text {filtr }}=(2-5) \times 10^{-7}\right.$ $\mathrm{cm} / \mathrm{sec}$ ). Thick films on $a-\mathrm{Al}_{2} \mathrm{O}_{3}$ (polycor) substrates based on weakly agglomerated nanopowders were deposited by tape casting. The thickness of thick films was $15-18 \mu \mathrm{m}$, the grain size was $0.5-1.5 \mu \mathrm{m}$. Thick films have a conductivity of $4 \cdot 10^{-4} \mathrm{~S} / \mathrm{cm}$ at $600{ }^{\circ} \mathrm{C}$ and $2.4 \cdot 10^{-3} \mathrm{~S} / \mathrm{cm}$ at $700{ }^{\circ} \mathrm{C}$; an activation energy of $1.17 \mathrm{eV}$; and their electron conductivity is lower than oxygen conductivity by 4 orders of magnitude. A multilayer system, which consists of a film of polycrystalline porous anode and solid electrolyte, was prepared. The use of an organic additive (tannin), laminating, thermal shock $\left(500^{\circ} \mathrm{C} / \mathrm{min}\right)$ and heat treatment at optimum temperature $\left(1100-1300{ }^{\circ} \mathrm{C}\right)$ prevents diffusion of cations from polycrystalline anode to the thick-film electrolyte and back and change in the chemical composition of the electrolyte. The multilayer systems can be used for the manufacturing of low temperature $\left(600^{\circ} \mathrm{C}\right)$ fuel cells with film structure.

\section{References}

[1] Kawamura K, Watanabe K, Hiramatsu T, Kaimai A, Nigara Y, Kawada T, et al. Electrical conductivities of $\mathrm{CaO}$ doped $\mathrm{ZrO}_{2}-\mathrm{CeO}_{2}$ solid solution system. Solid State Ionics. 2001;144(1):11-8.

[2] Lee J-H, Kim J, Kim S-W, Lee H-W, Song H. Characterization of the electrical properties of $\mathrm{Y}_{2} \mathrm{O}_{3}-$ doped $\mathrm{CeO}_{2}$-rich $\mathrm{CeO}_{2}-\mathrm{ZrO}_{2}$ solid solutions. Solid State Ionics. 2004;166(1):45-52.

[3] Belous A, Kravchyk K, Pashkova E, Bohnke O, Galven C. Influence of the Chemical Composition on Structural Properties and Electrical Conductivity of $\mathrm{Y}-\mathrm{Ce}-\mathrm{ZrO}_{2}$. Chem Mater. 2007;19(21):5179-84.

[4] Badwal S, Ciacchi F, Milosevic D. Scandiazirconia electrolytes for intermediate temperature solid oxide fuel cell operation. Solid State Ionics. 2000;136:919.

[5] Kosacki I, Anderson HU, Mizutani Y, Ukai K. Nonstoichiometry and electrical transport in Sc-doped zirconia. Solid State Ionics. 2002;152:431-8.

[6] Belous A, V'yunov O, Gunes V, Bohnke O. Ionic and electronic conductivities of yttria- and scandiastabilized zirconia. Inorg Mater. 2014;50(12).

[7] Bohnke O, Gunes V, Kravchyk K, Belous A, Yanchevskii O, V'yunov $\mathrm{O}$. Ionic and electronic conductivity of $3 \mathrm{~mol} \% \mathrm{Fe}_{2} \mathrm{O}_{3}$-substituted cubic yttriastabilized $\mathrm{ZrO}_{2}$ (YSZ) and scandia-stabilized $\mathrm{ZrO}_{2}$ (ScSZ). Solid State Ionics. 2014;262:517-21.

[8] Yanchevskii OZ, Kovalenko LL, Belous AG. Codoping of Scandium-Containing Zirconia-Based Solid Electrolytes with Iron, Cerium, and Copper Oxides. Inorg Mater. 2016;52(3):301-8.

[9] Winburn RS, Grier DG, McCarthy GJ, Peterson RB. Rietveld quantitative X-ray diffraction analysis of NIST fly ash standard reference materials. Powder Diffr. 2000;15(03):163-72. 